\title{
Penicillin allergies: referral and management practices of anesthesiologists
}

\author{
V Jain ${ }^{1 *}, \mathrm{~N}$ Joshi $^{2}, \mathrm{M} \mathrm{Sidhu}^{3}$, C Kalicinsky ${ }^{1}$, T Pun $^{1}$ \\ From Canadian Society of Allergy and Clinical Immunology Annual Scientific Meeting 2014 \\ Ottawa, ON, Canada. 23-26 October 2014
}

\section{Rationale}

Penicillin and other beta-lactams are the most commonly used antibiotics due to their narrow spectrum of activity, low cost and safety profile. However, an "allergy" to Penicillin is also the most commonly reported allergy. Approximately, 5-10\% of all patients self-report an allergy to Penicillin and of these $<10 \%$ are found to have true IgE mediated allergy on skin testing.

Numerous studies have confirmed the usefulness and strong negative predictive value ( $>99 \%)$ of skin testing to rule out true IgE mediated Penicillin allergy. Less than $10 \%$ of patients with a history of penicillin allergy are found to be actually allergic to penicillin on skin testing. Despite this, most physicians forgo further investigations in favor of the usage of alternative antibiotics.

\section{Methods}

A questionnaire was designed to evaluate the referral practices of Anesthesiologists for a presumed Penicillin allergy.

The preliminary study was administered as a semistructured interview to Anesthesiology Staff Physicians and Senior Residents at Memorial University of Newfoundland. The responses were analyzed using recursive abstraction

\section{Results}

$89.5 \%$ of respondents have never referred patients for evaluation of drug allergy, although, an equal number felt a referral would be helpful. However, $47.3 \%$ said they have verbally communicated to their patients that they should speak to their Family Doctor for work up of their allergy. $21.1 \%$ of participants felt time constraint was a barrier to creating a referral; another $15.8 \%$ felt that this

\footnotetext{
${ }^{1}$ Allergy \& Clinical Immunology, University of Manitoba, Winnipeg, MB, R3T 2N2, Canada

Full list of author information is available at the end of the article
}

was the responsibility of another physician (Surgeon or Family Doctor). An additional $26.3 \%$ did not comment on barriers but stated they would just give an alternative medication rather than refer. Another $15.8 \%$ mentioned that surgery is generally imminent and would not delay surgery to a referral. All participants stated they would choose an alternative antibiotic in the case of a history of penicillin allergy.

\section{Conclusion}

Carrying a presumed diagnosis of penicillin "allergy" has significant consequences on the health care system and patient outcome. Anesthesiologists in our study do inquire about specifics of allergy history, however, the referrals are virtually non-existent. As a result, anesthesiologists are prescribing more expensive antibiotics, which have higher potential for emergence of antibiotic resistance. Our future plans are to complete data collection at other centers and to develop an intervention to improve referral practices and study its impact.
Authors' details
${ }^{1}$ Allergy \& Clinical Immunology, University of Manitoba, Winnipeg, MB, R3T 2N2, Canada. ${ }^{2}$ Department of Internal Medicine, Memorial University of Newfoundland, St. John's, NL, A1B 3X9, Canada. ${ }^{3}$ Department of Family Medicine, University of Western Ontario, London, ON, N6A 3K7, Canada.
Published: 18 December 2014
References
1. Lee $A U$, et al: The incidence of antimicrobial allergies in hospitalized patients: implications regarding prescribing patterns and emerging bacterial resistance. Arch Intern Med 2000, 160(18):2819.
2. Gadde J, Spence M, Wheeler B, et al: "Clinical experience with penicillin skin testing in a large inner-city STD clinic". JAMA 1993, 270:2456-63.
3. Macy Eric, Richard Contreras: "Health Care Use and Serious Infection Prevalence Associated with Penicillin "allergy" in Hospitalized Patients: A cohort Study.". Journal of Allergy and Clinical Immunology 2013.
4. Phillips Elizabeth: "Cost-effectiveness Analysis of Six Strategies for Cardiovascular Surgery Prophylaxis in Patients Labeled Penicillin Allergic.". Am. J. of Health-Systems Pharm 2000, 57:339. 
5. Picard Matthieu, Philippe Bégin: "Treatment of Patients with a History of Penicillin Allergy in a Large Tertiary-Care Academic Hospital.". The Journal of Allergy and Clinical Immunology 2013, 252-57, Practice 1.3.

6. Sade K, Holtzer I, Levo Y: "The Economic Burden of Antibiotic Treatment of Penicillin-allergic Patients in Internal Medicine Wards of a General Tertiary Care Hospital.". Clinical Experimental Allergy 2003, 33(4):501-06.

7. Warrington, Silviu-Dan : Allergy, Asthma \& Clinical Immunology 2011 , 7(Suppl 1):S10.

doi:10.1186/1710-1492-10-S2-A20

Cite this article as: Jain et al.: Penicillin allergies: referral and

management practices of anesthesiologists. Allergy, Asthma and Clinical

Immunology 2014 10(Suppl 2):A20.

Submit your next manuscript to BioMed Central and take full advantage of:

- Convenient online submission

- Thorough peer review

- No space constraints or color figure charges

- Immediate publication on acceptance

- Inclusion in PubMed, CAS, Scopus and Google Scholar

- Research which is freely available for redistribution

Submit your manuscript at www.biomedcentral.com/submit 